\title{
MATHEMATICAL MODEL FOR GREENHOUSE HEATING BY WASTE HEAT FROM BIOGAS FUEL ENGINE
}

Gamea, G. R.*

Abd El-Maksoud, M. A.*

Omar, M. N.**

\begin{abstract}
A mathematical model consisting of algebraic equations was developed for greenhouse heating integrated with a heater exchanger. The works on the principal of utilizing the waste heat from the biogas fuel engine. The equations were used by MATLAB program for four components of the greenhouse, cover, inside air, plant and soil. It was assumed that the greenhouse air is well mixed. Thermal properties of construction materials are constant and solar radiations pass through cover without absorption. The analysis is based on the energy balance equations for different components of the greenhouse. The model is developed to calculate the hourly temperatures of greenhouse components under climatic parameters. Experimental validation of the developed model is carried out in Ostobary, Shibin El-Kom, Minofiya latitude angle is $30^{\circ} 54^{\prime}$ north during November 2009 to March 2010. The results of computer model (predicted data) were compared with the experimental results. The minimum correlation coefficients between values were $0.970,0.975$, $0.970,0.977$ and 0.818 for air, soil, cover, plant and relative humidity respectively. The minimum temperatures were 13, 12.77, 13.57 and 15.8 ${ }^{\circ} \mathrm{C}$ for air, cover, plant and soil. Good agreement between the predicted and measured values was obtained during the entire modelling period. This means that the model can be used to predict a thermal performance of the greenhouse elements in a wide range of solar radiation and temperatures. Using waste heat as an input for greenhouse operations is a new mechanism for reducing operating costs.
\end{abstract}

Keywords: Biogas, Model, Waste, Greenhouse, Heating, Exchanger.

\footnotetext{
*Associate professor of Agricultural Engineering, Faculty of Agriculture, Minofiya University.

**Associate Lecturer of Agricultural Engineering, Faculty of Agriculture, Minofiya University.
} 


\section{INTRODUCTION}

7 he world population is expected to rise in the next years. In order to feed these people, there is a need to increase the quantity of

1 food product in sustainable way. Greenhouses allow producers to grow plants at time and location when it would be impossible to grow outside because of the adverse climate, pests and diseases. In order to achieve maximum returns from greenhouse cultivation, it is important to maintain an environment that promotes optimum plant growth and production all year round. The growth factors namely: light, temperature, humidity and air composition should be delivered and maintained at optimal levels. To maintain this optimum growing environment, greenhouses ought to allow high light transmittance, heat consumption, sufficient ventilation efficiency, low construction and operating costs Mutwiwa (2007). To be able to utilize greenhouses to produce agricultural products outside the normal cultivation season, it is necessary to heat them, particularly during the cold seasons. Applying heating in the greenhouses has an important effect on the yield as well as on the quality and on the cultivation time of the products as well. As energy costs are increasing, many greenhouse operators are re-evaluating energy consumption and savings strategies. In most cases, updating older heating systems to more efficient units in addition to the use of double layer glazing, insulation materials, and energy curtains significantly reduces fuel consumption. But the energy crisis of the next few years is the shortage of fuel for the daily needs of millions of people. Simple biogas is intended to help solve this problem Gautam et al. (2007).

\section{Nomenclature}

$\begin{array}{llc}\mathrm{A}_{c o} & \text { cover surface area } & \mathrm{m}^{2} \\ \mathrm{~A}_{p l} & \text { plant surface area } & \mathrm{m}^{2} \\ \mathrm{~A}_{s o} & \text { soil surface area } & \mathrm{m}^{2} \\ \mathrm{~b} & \text { cloudiness factor in the range from 0 to 1 } & - \\ L & \text { thickness of the soil } & \mathrm{m} \\ m_{w} & \text { mass of water } & \mathrm{kg} \\ n & \text { selected simulation time } & \mathrm{h} \\ p_{a} & \text { atmospheric pressure } & \mathrm{kPa}\end{array}$




\begin{tabular}{|c|c|c|}
\hline$P_{w v}$ & water vapour pressure & $\mathrm{kpa}$ \\
\hline$p_{w v s}$ & aturated vapour pressure & $\mathrm{kPa}$ \\
\hline$P_{w v s}$ & $\begin{array}{l}\text { aturation vapor pressure at the dry- bulb } \\
\text { emperature }\end{array}$ & $\mathrm{kPa}$ \\
\hline$P_{w v s}^{*}$ & $\begin{array}{l}\text { aturation vapor pressure at the wet- bulb } \\
\text { emperature }\end{array}$ & $\mathrm{kPa}$ \\
\hline$Q_{\text {vent }}$ & $\begin{array}{l}\text { heat loss from greenhouse air due to } \\
\text { ion }\end{array}$ & $\mathrm{Wm}^{-2}$ \\
\hline$Q_{\text {evap }}$ & $\begin{array}{l}\text { ermal heat loss from greenhouse soil due to } \\
\text { aporation }\end{array}$ & $\mathrm{Wm}^{-2}$ \\
\hline$Q_{\text {heating }}$ & thermal radiation from the heating system & $\mathrm{Wm}^{-2}$ \\
\hline$Q_{r d(c o-s k y)}$ & thermal radiation loss from cover to sky & $\mathrm{Wm}^{-2}$ \\
\hline$Q_{h}$ & $\begin{array}{l}\text { total thermal energy transferred from heating } \\
\text { system }\end{array}$ & \\
\hline$Q_{r d(c o-p l)}$ & $\begin{array}{l}\text { radiation exchange between the cover and } \\
\text { plant }\end{array}$ & $\mathrm{Wm}^{-2}$ \\
\hline$Q_{r d(c o-s o)}$ & radiation exchange between the cover and soil & $\mathrm{Wm}^{-2}$ \\
\hline$Q_{r d(p l-s o)}$ & radiation exchange between the plant and soil & $\mathrm{Wm}^{-2}$ \\
\hline$Q_{c d}$ & nergy loss from the soil to the ground & $\mathrm{Wm}^{-2}$ \\
\hline$Q_{\text {trans }}$ & heat flow due to transpiration & $\mathrm{Wm}^{-2}$ \\
\hline$Q_{c d(s o)}$ & heat flux due to conduction from soil to air & $\mathrm{Wm}^{-2}$ \\
\hline$Q_{C V(c o)}$ & to convection from cover to air & $\mathrm{Wm}^{-2}$ \\
\hline$Q_{C V(p l)}$ & heat flux due to convection from plant to air & $\mathrm{Wm}^{-2}$ \\
\hline$Q_{L t}$ & latent 1 & $\mathrm{Wm}^{-2}$ \\
\hline$Q_{\text {conden }}$ & latent heat of condensation & $\mathrm{Wm}^{-2}$ \\
\hline$Q_{S i}$ & sensible heat & $\mathrm{Wm}^{-2}$ \\
\hline$Q_{G(p l)}$ & solar energy absorbed by plant surface & $\mathrm{Wm}^{-2}$ \\
\hline$Q_{G(s o)}$ & solar energy absorbed by soil surface & $\mathrm{Wm}^{-2}$ \\
\hline$r$ & ation & Whg $^{-1}$ \\
\hline RH & ity & {$[\%$} \\
\hline & & \\
\hline & nside air temperature & ${ }^{\mathrm{o}} \mathrm{C}$ \\
\hline$T_{\text {in }}$ & design interior air temperature in the night & ${ }^{\circ} \mathrm{C}$ \\
\hline
\end{tabular}




\begin{tabular}{|c|c|c|}
\hline $\mathrm{T}_{\text {out }}$ & outside ambient air temperature & ${ }^{\circ} \mathrm{C}$ \\
\hline $\mathrm{T}_{p l}$ & leaf surface temperature & $\mathrm{K}$ \\
\hline $\mathrm{T}_{\text {sky }}$ & sky temperature & K \\
\hline $\mathrm{T}_{\text {so }-\mathrm{x}=0}$ & temperature at the surface soil & K \\
\hline $\mathrm{T}_{\text {so }-\mathrm{x}=1:}$ & temperature at the soil depth & $\mathrm{K}$ \\
\hline $\mathrm{T}_{(c o)}$ & cover surface temperature & ${ }^{\circ} \mathrm{C}$ \\
\hline$t_{d r y}$ & dry-bulb temperature & ${ }^{\circ} \mathrm{C}$ \\
\hline t & simulation time & $\mathrm{h}$ \\
\hline$V_{g}$ & greenhouse volume & $\mathrm{m}^{3}$ \\
\hline$v_{\omega}$ & wind velocity & $\mathrm{ms}^{-1}$ \\
\hline$x_{i n s}$ & water content of inside greenhouse air & $\mathrm{kgkg}^{-1}$ \\
\hline$x_{\text {out }}$ & water content of outside greenhouse air & $\mathrm{kgkg}^{-1}$ \\
\hline$x_{\text {sat }}$ & water content of the saturated air & $\mathrm{kgkg}^{-1}$ \\
\hline$x_{\text {sat }(c o)}$ & $\begin{array}{l}\text { saturation water content at the cover surface } \\
\text { temperature }\end{array}$ & $\mathrm{kgkg}^{-1}$ \\
\hline$x_{\text {sat }(s o)}$ & $\begin{array}{l}\text { saturation water content at the soil surface } \\
\text { temperature }\end{array}$ & $\mathrm{kgkg}^{-1}$ \\
\hline$x_{\text {sat }(p l)}$ & $\begin{array}{l}\text { saturation water content at the plant } \\
\text { temperature }\end{array}$ & $\mathrm{kgkg}^{-1}$ \\
\hline$Z$ & air exchange number & $\mathrm{h}^{-1}$ \\
\hline$\tau$ & transmissivity of the cover & - \\
\hline$\alpha_{(c o)}$ & $\begin{array}{l}\text { coefficient of convective thermal transmission } \\
\text { from cover }\end{array}$ & $\mathrm{Wm}^{-2}{ }^{\circ} \mathrm{C}^{-1}$ \\
\hline$\alpha_{(p l)}$ & $\begin{array}{l}\text { coefficient of convective thermal transmission } \\
\text { from plant }\end{array}$ & $\mathrm{Wm}^{-2}{ }^{\circ} \mathrm{C}^{-1}$ \\
\hline$\alpha_{(s o)}$ & $\begin{array}{l}\text { coefficient of convective thermal transmission } \\
\text { from soil }\end{array}$ & $\mathrm{Wm}^{-2}{ }^{\circ} \mathrm{C}^{-1}$ \\
\hline$\alpha_{(h)}$ & $\begin{array}{l}\text { coefficient of convective thermal transmission } \\
\text { from the hot exhaust gas in the pipe to the } \\
\text { greenhouse air }\end{array}$ & $\mathrm{Wm}^{-20} \mathrm{C}^{-1}$ \\
\hline$\psi$ & constant factor & $\mathrm{m}^{-1}$ \\
\hline$\varepsilon_{(p l-c o)}$ & $\begin{array}{l}\text { effective emissivity between cover surface and } \\
\text { plant }\end{array}$ & - \\
\hline$\varepsilon_{(c o, s o)}$ & $\begin{array}{l}\text { effective emissivity between cover surface and } \\
\text { soil }\end{array}$ & - \\
\hline
\end{tabular}




$\begin{array}{lll}\varepsilon_{(p l, s o)} & \text { effective emissivity between plant surface and } & - \\ \varepsilon_{c o} & \text { soil } & - \\ \varepsilon_{p l} & \text { emissivity of the cover } & - \\ \varepsilon_{s o} & \text { emissivity of the plant } & - \\ \alpha_{i n s} & \text { heat transfer coefficient inside the greenhouse } & \mathrm{Wm}^{-2} \mathrm{~K}^{-1} \\ \alpha_{P l} & \text { leaf surface absorption } & - \\ \alpha_{g} & \text { soil surface absorption } & - \\ \sigma & \text { Stefan-Boltzmann constant } & \mathrm{Wm}^{-2} \mathrm{~K}^{-4} \\ \lambda & \text { thermal conductivity of the soil } & \mathrm{Wm}^{-1} \mathrm{~K}^{-1}\end{array}$

Because of the relatively high cost and uncertain availability of fossil fuels, considerable attention has been given to a new and renewable energy sources as an alternative means of heating greenhouses Oeztuerk and Baescetin-celik (2003). Using waste heat as an input for greenhouse operations is proposed as a mechanism for reducing operating costs. Because heat is such a major expense for operating greenhouses, the cost savings associated with obtaining it for free could theoretically be quite substantial. Internal combustion can be coupled with a generator to produce electricity. Heat can also be recovered, both from the exhaust gas and from the engine cooling system with heating efficiencies in the range 60 to $70 \%$ Willits et al., (2003). Biogas production is a key technology for using the agrarian biomass as renewable energy source, and solves the problem of environmental pollution. High energy yields from agricultural wastes can be achieved through biogas production. Biogas can be produced from a wide range of energy crops, animal manures and organic wastes. Thus, it offers a high flexibility and can be adapted to the specific needs of contrasting locations and farm managements. After anaerobic digestion, the digestion residues can be used as a valuable fertilizer for agricultural crops Amon et al., 2007. The main objective of the study is to Simulated and validation of a mathematical model for Optimization of using waste heat from an engine biogas fuel for greenhouse heating. 


\section{MATERIALS AND METHODS}

\subsection{Mathematical modells}

The model was designed for evaluation performance the greenhouse that heating with the exhaust gas from the engine. Heat transfer is energy in transit due to a temperature difference between two nodes with different temperatures Oeztuerk (2005). The equations were written for four components of the greenhouse that's, cover, inside air, plants surface and soil surface. The equations were solved using Matlab program. The temperature of each node is spatially uniform. The thermal radiative, sensible, latent, and conductive heat fluxes were modelled by mathematical equations in terms of unknown temperatures and vapour pressures. The energy balance equations were then developed for each node in the experimental greenhouse, where the sum of the fluxes at that node should be zero. The equations were solved by an integrative procedure to obtain the unknown temperatures and vapour pressures. Figure (1) shows the model of the heat dynamics for different components of the greenhouse.

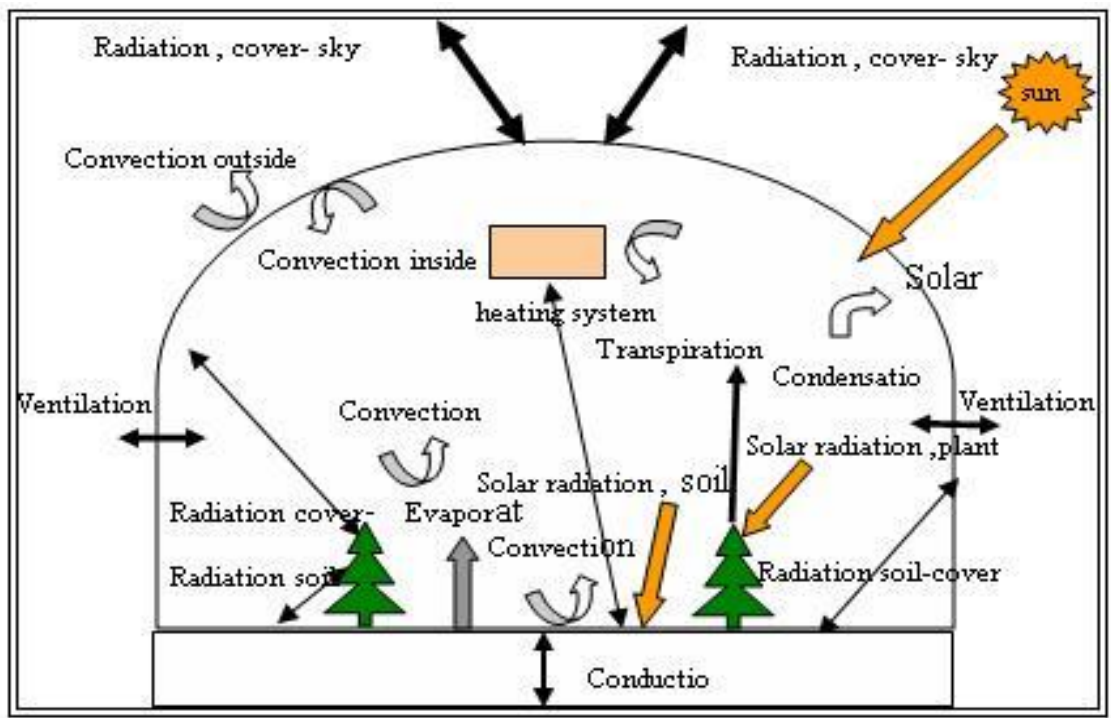

Fig.1: Energy balance and fluxes of the all components of the greenhouse.

\subsubsection{The greenhouse air}

In the energy balance of inside air of greenhouse, only the convective heat transfer is considered. It is assumed that no thermal or solar radiation is 
absorbed by the air. The energy balance for the air inside the greenhouse show in the following equations:

$$
Q_{C V(P L)}+Q_{C V(S O)}+Q_{C V(C O)}+Q_{h}+Q_{v e n t}=0
$$

Where

$$
\begin{aligned}
& Q_{C V(P L)}=\alpha_{(P L)}\left\lfloor\mathrm{T}_{(p l)}-\mathrm{T}_{(a i r)}\right\rfloor, \mathrm{Wm}^{-2} \\
& \left.Q_{C V(s o)}=\alpha_{(s o)} \mid \mathrm{T}_{(s o)}-\mathrm{T}_{(a i r)}\right\rfloor, \mathrm{Wm}^{-2} \\
& Q_{C V(c o)}=\alpha_{(c o)}\left\lfloor\mathrm{T}_{(c o)}-\mathrm{T}_{(a i r)}\right\rfloor, \mathrm{Wm}^{-2} \\
& Q_{h}=\alpha_{h}\left\lfloor T_{(g a s)}-T_{(a i r)}\right\rfloor, \mathrm{Wm}^{-2}
\end{aligned}
$$

The energy removed by ventilation consists of sensible and latent heat. The net energy flux $Q_{v e n t}$ from inside to outside due to ventilation through a ventilation opening can be easily calculated according to Harmanto (2006) as follows:

$$
Q_{\text {vent }}=Q_{S i}+Q_{L t}=\frac{Z V_{g} \rho}{A}\left[\left(\mathrm{~T}_{(\text {ins })}-\mathrm{T}_{(\text {out })}\right) C_{P}+\left(x_{\text {ins }}-x_{\text {out }}\right) r\right], \mathrm{Wm}^{-2}
$$

Where $Z$ is the air exchange number and calculated according to Von Elsner (1982), $Z=\psi v_{\omega}+0.25, \mathrm{~h}^{-1}$

\subsubsection{The greenhouse soil}

The soil surface gains heat from thermal radiations emitted through greenhouse cover and absorbed by the soil surface and the thermal radiation from the heating system. The soil in the greenhouse is considered a large heat storage element Tantau (1998). It loses heat through the thermal radiations emitted by the soil surface, conduction through the soil and convective heat transfer form the soil surface to the inside air.

$$
Q_{G(s o)}+Q_{r d(p l-s o)}+Q_{r d(c o-s o)}+Q_{c v(s o)}+Q_{c d}+Q_{\text {evap }}+Q_{\text {heating }}=0
$$

The soil surface gains heat from thermal radiations emitted through greenhouse cover and absorbed by the soil surface calculated according to Singha et al (2006) as follows: 


$$
\begin{aligned}
& Q_{G(s o)}=\alpha_{g}\left(1-\alpha_{p}\right) \tau S_{t}, \mathrm{Wm}^{-2} \\
& Q_{r d(p l-s o)}=\varepsilon_{(p l, s o)}\left(\frac{\mathrm{A}_{s o}}{\mathrm{~A}_{p l}}\right) \sigma\left[\mathrm{T}_{p l}^{4}-\mathrm{T}_{s o}^{4}\right], \mathrm{Wm}^{-2} \\
& \varepsilon_{(p l, s o)}=\frac{1}{\frac{1}{\varepsilon_{p l}}+\frac{A_{s o}}{A_{p l}}\left(\frac{1}{\varepsilon_{s o}}-1\right)},- \\
& Q_{r d(c o-s o)}=\varepsilon_{(c o, s o)}\left(\frac{\mathrm{A}_{s o}}{\mathrm{~A}_{c o}}\right) \sigma\left[\mathrm{T}_{c o}^{4}-\mathrm{T}_{s o}^{4}\right], \mathrm{Wm}^{-2} \\
& Q_{c d(s o)}=\lambda \frac{\left[\mathrm{T}_{s o-x=0}-\mathrm{T}_{s o-x=l}\right]}{L}, \mathrm{Wm}^{-2} \\
& Q_{\text {evap }}=\frac{\alpha_{i n s}}{c p} r \zeta_{s o}\left(x_{s a t(s o)}-x_{i n s}\right), \mathrm{Wm}^{-2}
\end{aligned}
$$

Absolute humidity $\mathrm{x}_{\text {air }}$ is defined as the mass of water divided by the mass of dry air Lewis (1990).

$$
x_{\text {air }}=\frac{m_{w}}{m_{d}}, \mathrm{~kg} \mathrm{~kg}^{-1}
$$

Air becomes saturated when the water vapour pressure $P_{w v}$ is equal to the saturated vapour pressure, at given temperature. Therefore, the absolute humidity $\mathrm{x}_{\mathrm{sat}}$ of saturated air is given by the following equation:

$$
\begin{aligned}
& x_{\text {air }}=\frac{18 p_{w v}}{29\left(p_{a}-p_{w v}\right)}, \mathrm{kg} \mathrm{kg}^{-1} \\
& x_{s a t}=\frac{18 p_{w v s}}{29\left(p_{a}-p_{w v s}\right)}, \mathrm{kg} \mathrm{kg}^{-1}
\end{aligned}
$$

The following algorithm used for calculating saturation vapour pressure is limited to the range of temperatures from 0 to $100{ }^{\circ} \mathrm{C}$ Taha (2003). The determination of the saturation vapour pressure is the most important calculation in specifying moist air properties since all such properties are 
considered as a function of the vapour pressure. This equation is expressed as follows:

$$
p_{w v s}=0.61078 \exp \left[\frac{17.2693882 t}{t+273.3}\right], \mathrm{kPa}
$$

\subsubsection{The greenhouse plant}

The greenhouse-crop system can be considered as a solar collector involving both sensible and latent heat exchanges and its thermal performances can be described in a similar way by using energy balance equation Seginer and Alberight (1980). Part of the energy absorbed by the plants is transferred to latent heat due to transpiration. This energy flux resulting from the plants transpiration was mentioned in following equation Boulard et al., (1990).

$$
Q_{G(p l)}+Q_{r d(p l-c o)}+Q_{r d(p l-s o)}+Q_{c v(p l)}+Q_{\text {trans }}=0
$$

The heat gains from thermal radiations emitted through greenhouse cover and absorbed by the plants surface calculated according to Singha (2006) as follows:

$$
\begin{aligned}
& Q_{G(p l)}=\alpha_{p l} \tau S_{t}, \mathrm{Wm}^{-2} \\
& Q_{r d(p l-c o)}=\varepsilon_{(p l, c o)}\left(\frac{\mathrm{A}_{c o}}{\mathrm{~A}_{p l}}\right) \sigma\left[\mathrm{T}_{p l}^{4}-\mathrm{T}_{c o}^{4}\right], \mathrm{Wm}^{-2} \\
& \varepsilon_{(p l, c o)}=\frac{1}{\frac{1}{\varepsilon_{p l}}+\frac{A_{c o}}{A_{p l}}\left(\frac{1}{\varepsilon_{c o}}-1\right)},- \\
& Q_{\text {trans }}=\frac{\alpha_{i n s}}{c p} r \zeta_{p l}\left(x_{s a t(p l)}-x_{i n s}\right), \mathrm{Wm}^{-2}
\end{aligned}
$$

\subsubsection{The greenhouse cover}

Energy balance of the cover of greenhouse not includes solar radiations absorbed by the cover, convective heat transfer between cover and outside air, convective heat transfer between cover and inside air, thermal radiation exchange between cover and sky and latent heat transfer to cover by condensation. 


$$
\begin{aligned}
& Q_{r d(s o-c o)}+Q_{r d(p l-c o)}+Q_{r d(c o-s k y)}+Q_{C V(a i r) i n s}+Q_{c v(a i r) o u t}+Q_{c o n d}=0 \\
& Q_{r d(c o-s k y)}=\varepsilon_{c o} \sigma\left[\mathrm{T}_{c o}^{4}-\mathrm{T}_{s k y}^{4}\right], \mathrm{Wm}^{-2}
\end{aligned}
$$

The sky temperature can be calculated according to von Elsner (1983) equation as follows:

$$
\begin{gathered}
T_{\text {sky }}=1.2 T_{e}-21.4+b\left(20.6-0.26 T_{e}\right),{ }^{\circ} \mathrm{C} \\
Q_{\text {cnden }}=\frac{\alpha_{\text {ins }}}{c p} r \zeta\left[x_{\text {ins }}-x_{\text {sat }(c o)}\right], \mathrm{Wm}^{-2}
\end{gathered}
$$

\subsubsection{Calculation of the inside relative humidity}

To calculation the relative humidity $(\mathrm{RH})$ inside greenhouse by the model we want to calculation the moisture content of the inside air greenhouse and the saturation vapour pressure. Those are the most important calculation for RH. The following equations are used to determination the RH inside greenhouse:-

$$
R H=\frac{P_{w v}}{P_{w v s}} \times 100, \%
$$

\subsubsection{Differential equation:}

To calculate the temperature of the greenhouse elements (air, soil, plants and covering material) the following differential equation was used Taha (2003).

$$
T=\frac{1}{\rho c_{p} \delta} \int_{t=0}^{t=n}\left(Q_{\text {sup }}-Q_{l o s}\right) d t, \mathrm{k}
$$

\subsubsection{Model parameters and boundary conditions}

Various parameters affect on the behaviour of the model. These parameters are the typical features of the greenhouse which are divided into five internal layers: the cover, the internal air, the soil, the plants and the heating system, and four boundary layers: the solar radiations, the sky, the external air and the sub-soil. The optimum values obtained by this study are compared to that found in the literatures it can be seen in table (1). 
Table 1: Literature and optimum values of the parameters considered in the model.

\begin{tabular}{|c|c|c|c|}
\hline parameter & $\begin{array}{l}\text { Literature- } \\
\text { value }\end{array}$ & References & $\begin{array}{l}\text { Optimum } \\
\text { values }\end{array}$ \\
\hline$\alpha$ inside, $\mathrm{Wm}-{ }^{2} \mathrm{~K}-{ }^{1}$ & $\begin{array}{l}1.5 \text { to } 4 \\
1.25 \text { to } \\
10.9 \\
2 \text { to } 5\end{array}$ & $\begin{array}{l}\text { Taha et al ., } 2009 \\
\text { Shukla et al.2006 } \\
\text { Tantau } 1983\end{array}$ & $\begin{array}{l}3.25 \text { for soil } \\
, 4.9 \text { for } \\
\text { cover and } \\
\text { 9.3for plant }\end{array}$ \\
\hline $\begin{array}{l}\alpha \text { inside, } \mathrm{Wm}^{-2} \mathrm{~K}^{-1} \\
\text { heating pipes }\end{array}$ & $\begin{array}{ll}400 & \text { to } \\
4380 & \end{array}$ & Tantau 1983 & 900 \\
\hline$\alpha$ outside, $\mathrm{Wm}^{-2} \mathrm{~K}^{-1}$ & $\begin{array}{l}43 \text { to } 59 \\
4 \text { to } 30 \\
4 \text { to } 34 \\
\end{array}$ & $\begin{array}{l}\text { Kumari et al } 2003 \\
\text { Taha, } 2003 \\
\text { Tantau 1983, }\end{array}$ & 29 \\
\hline $\mathrm{Cp}$ (air), $\mathrm{Wh} \mathrm{Kg}^{-1} \mathrm{~K}^{-1}$ & 0.280 & He et al., 2009 & 0.28 \\
\hline $\mathrm{Cp}(\mathrm{so}), \mathrm{Wh} \mathrm{Kg}^{-1} \mathrm{~K}^{-1}$ & $\begin{array}{ll}0.51 \\
0.236 \quad \text { to } \\
0.4 & \\
\end{array}$ & $\begin{array}{l}\text { Singha, G. et al. } \\
2006 \\
\text { Elsheikh, } 2001\end{array}$ & 0.32 \\
\hline $\mathrm{Cp}(\mathrm{pl}), \mathrm{Wh} \mathrm{Kg}^{-1} \mathrm{~K}^{-1}$ & 0.9 to 1.3 & $\begin{array}{l}\text { Singha, G. et al. } \\
2006\end{array}$ & 1.16 \\
\hline$\lambda($ so $), \mathrm{Wm}^{-1} \mathrm{~K}^{-1}$ & $\begin{array}{l}0.8 \text { to } 2.3 \\
0.8\end{array}$ & $\begin{array}{l}\text { Taha, 2003, } \\
\text { Elsheikh } 2001 \\
\text { Singha, G. et al. } \\
2006\end{array}$ & 0.8 \\
\hline$\varphi \mathrm{Cm},-$ & 0.25 to 0.4 & $\begin{array}{l}\text { Taha, 2003, } \\
\text { Elsheikh, } 2001\end{array}$ & $0.25-0.40$ \\
\hline$\varphi s o,-$ & 0.9 & $\begin{array}{l}\text { Ghosal, } \quad \text { M.K. } \\
\text { Tiwari, G.N. } 2006\end{array}$ & 0.9 \\
\hline$\varphi \mathrm{sk},-$ & $\begin{array}{l}1 \\
0.5 \text { to } 1.0\end{array}$ & $\begin{array}{l}\text { ELSheikh } 2001 \\
\text { Strauch } 1985\end{array}$ & 1 \\
\hline$\zeta($ So $),-$ & 0.0 to 0.8 & Strauch 1985 & 0.60 \\
\hline$\zeta(\mathrm{p}),-$ & 0.40 & Taha, 2003 & 0.40 \\
\hline
\end{tabular}




\subsection{Experimental setup}

The experimental setup used in this work shows in the schematic diagram figure (2).

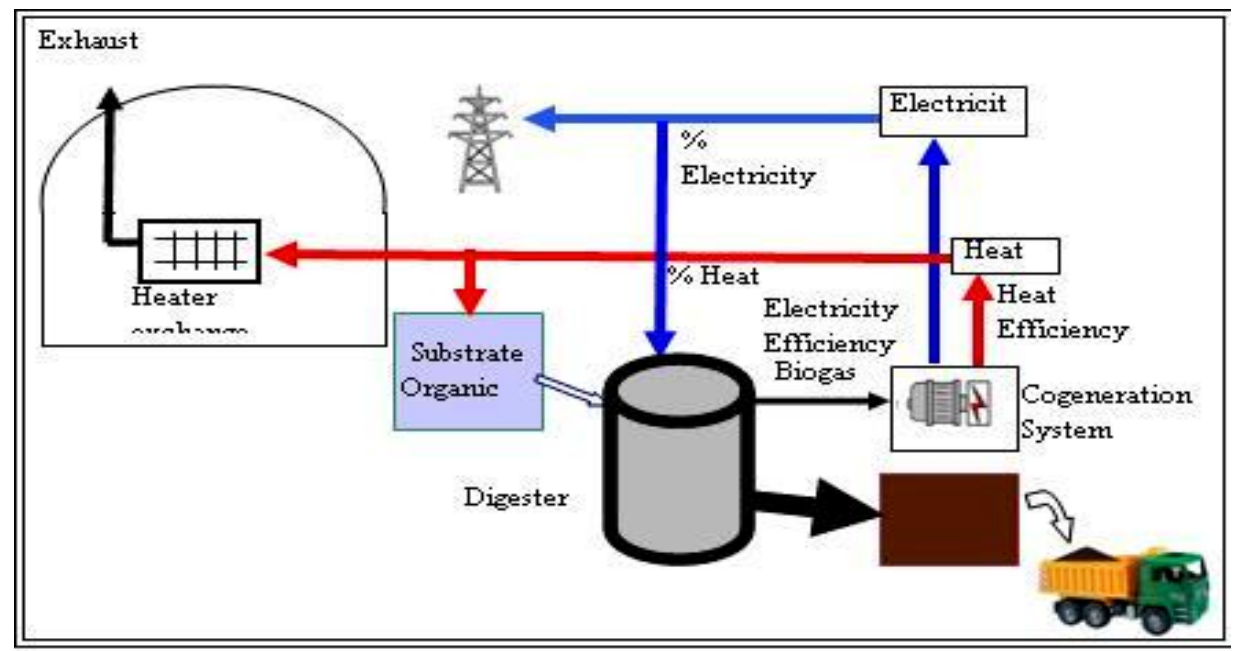

Fig.2: Schematic diagram show the experimental setup.

\subsubsection{Greenhouse construction and roof material}

To achieve the objectives of the study, a Quonset greenhouse with heat exchanger unit constructed were carried out during winter 2009/2010 season and installed in Ostobary village, Shibin El-Kom, Minofiya (Geographically, the chosen place's latitude angle is $30^{\circ} 54^{\prime}$ degrees), was used. The direction of the greenhouse was east-west to take the maximum benefit from the sun during winter. The total area under the greenhouse is $71.5 \mathrm{~m}^{2}$ with the dimensions as $5.6 \times 13.5 \mathrm{~m}$. the Experimental greenhouse has 7 rows with $80 \mathrm{~cm}$ width. The frame of the greenhouse was fabricated using Iron skewers. The distances between the skewers were fixed $1.5 \mathrm{~m}$ figure (3). The height of the greenhouse at the centre is $3.0 \mathrm{~m}$. The vertical of the side walls were $1.5 \mathrm{~m}$. The greenhouse frame was covered with a single polyethylene sheet of 200-mm-thickness.

\subsubsection{Crops cultivation and irrigation system}

Cucumber is one of the important vegetable crops in the world also in Egypt. Cucumber plants were grown in Trays in the Arboretum for one month and after that transferred to greenhouse in 20 November 2009, 
placed at $0.80 \mathrm{~m}$ spacing between the rows and $0.40 \mathrm{~m}$ within a row. The number of cucumber plants in the greenhouse $225\left(3.125 \mathrm{plant} / \mathrm{m}^{2}\right)$ Abdelmenim (1998). The optimum temperature required for the plants was in the day about $20-24^{\circ} \mathrm{C}$ and in the night about $15-18^{\circ} \mathrm{C}$ according to Abdelmenim (1998).

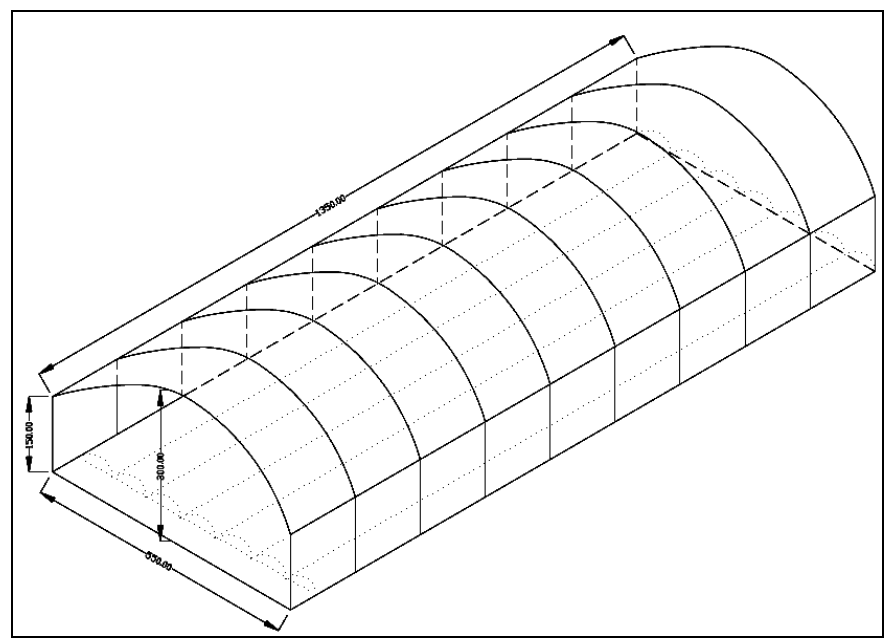

Fig.3-a: Isometric view of the greenhouse used.

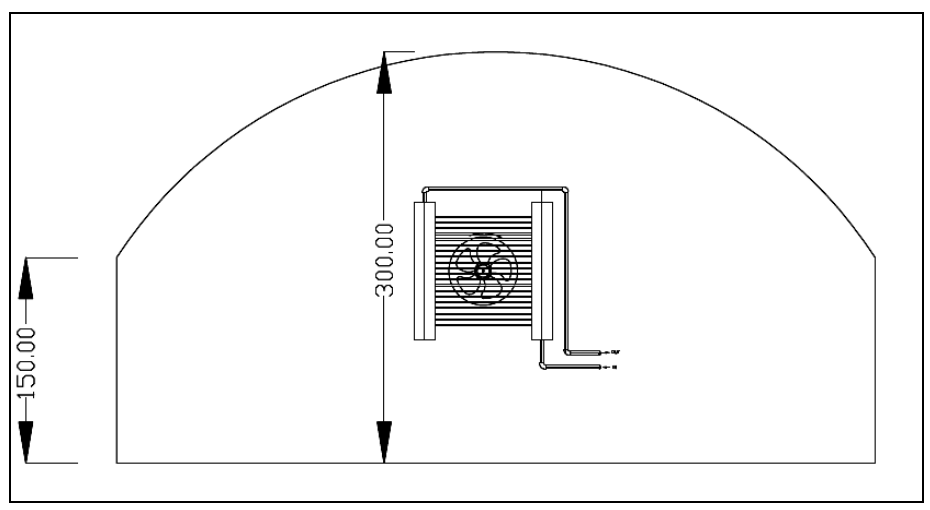

Fig.3-b: Elevation of the greenhouse used in the experimental study.

\subsubsection{Heat Exchanger}

The heat exchanger is designed to remove heat from the exhaust gas of an engine and transfer it to the greenhouse. It is the most equipment commonly used to heat the greenhouse.

\subsubsection{The experimental Engine}


The engine used in this study was a 5 HP Water Cooled Diesel Engine. The engine is of the $553 \mathrm{~cm}^{3}$, single cylinder type with overhead valves. The combustion chamber is cylindrical in shape with the compression ratio of 17:1. The four-stroke, naturally aspirated, water-cooled, compression ignition engine is nominally rated at $3.7 \mathrm{~kW}$ at $1500 \mathrm{rpm}$ and $25 \mathrm{Nm}$ of torque at $1900 \mathrm{rpm}$. Biogas was supplied through a plastic pipe and mixed with inlet air from the engine filter air.

\subsection{Measurements}

\subsubsection{Solar radiation}

Pyranometers CM 6 was used to measure the solar irradiation outside the greenhouse which fixed in a height of $2.5 \mathrm{~m}$.

\subsubsection{Temperatures}

The air temperature inside greenhouse, air temperature outside greenhouse, soil temperature, plant temperature and cover temperature were measured using IC (LM35) sensors. The data collection and recording frequency were recorded every 5 seconds and 1 hour average of each measurement by using a LabJacks data logger.

\subsubsection{Relative humidity}

To measure the inside and the outside humidity, aspirated psychrometers which have been developed at the institute of Horticulture and Agricultural Engineering, Hannover University, were used.

\section{RESULTS AND DISCUSSION}

The results of the modell validation were discussed under the following heads:

\section{1 -Greenhouse air temperature}

The calculated temperatures of inside air greenhouse using the computer model along with arithmetic average of measured values at different time of the day are shown in figure (4). The air temperatures inside greenhouse fluctuated with the daily amplitude becoming larger at the noon. It reached the peak at noon and declined in late afternoon and early morning. The air temperature inside the closed greenhouse reached the 
maximal values were 36.92 and $38.5{ }^{\circ} \mathrm{C}$ in January and February and the minimum value were 13.59 and $13{ }^{\circ} \mathrm{C}$ in January and February.

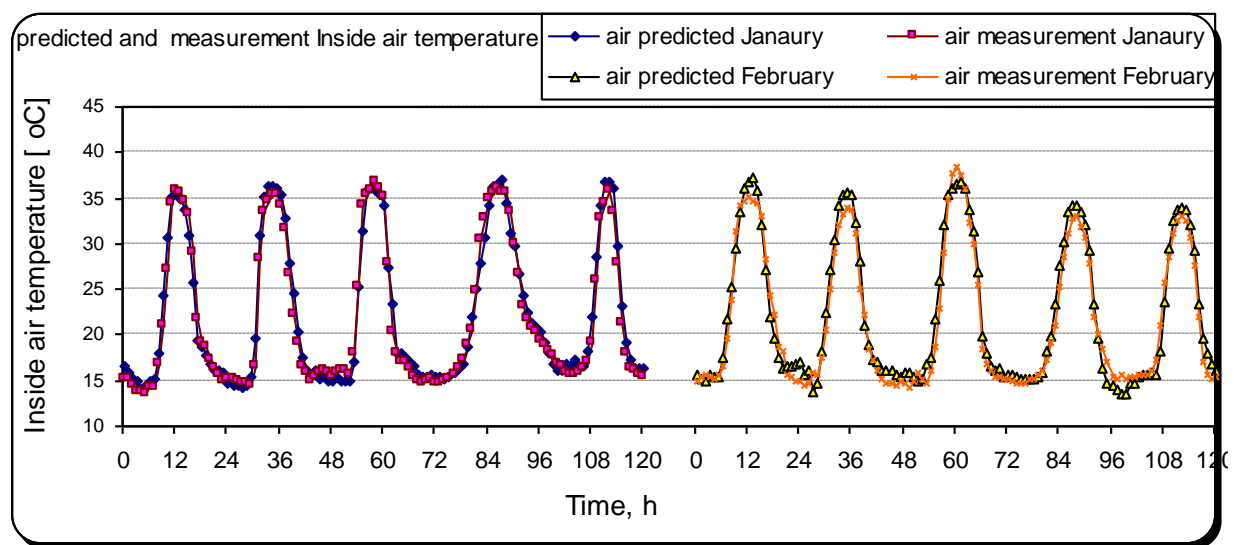

Fig.4: predicted and measured inside air temperature of the greenhouse.

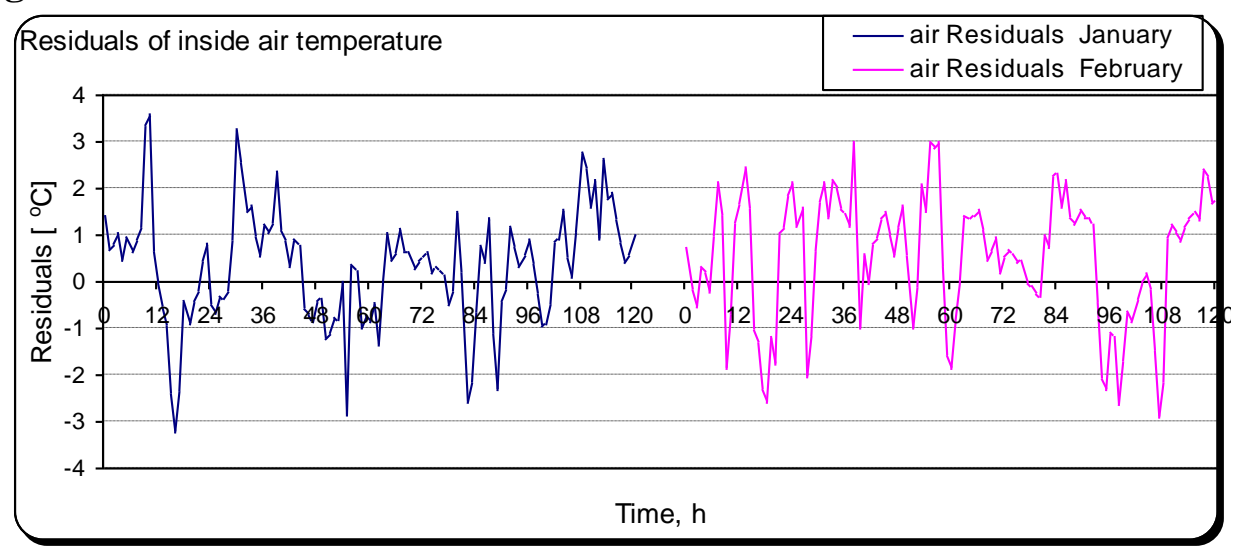

Fig.5: Residuals of the measured and predicted inside air temperature.

It can be observed that, the maximum difference between measured and predicted temperature was $3.59{ }^{\circ} \mathrm{C}$ in January figure (5). The minimum correlation coefficient between values was 0.970 in February figure (6). 

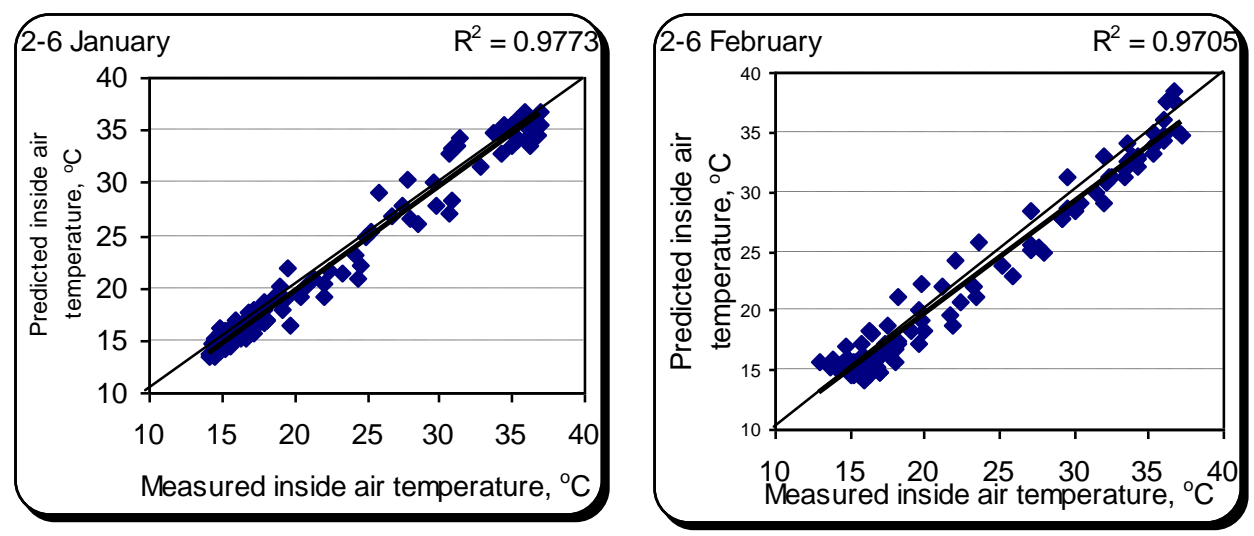

Fig.6: Comparison between measured and predicted of the inside air temperature.

And there is a correspondence between the simulated and the measured air temperatures inside the greenhouse. The air temperature inside greenhouse is influenced by air temperature outside the greenhouse, incident global solar radiation and heating system.

\subsection{Greenhouse plant temperature}

Figure (7) present the simulation results obtained from the model during the simulation periods and the measurement in the same time. The plant temperature inside the closed greenhouse reached $37.17{ }^{\circ} \mathrm{C}$ in January, while it is $36.3{ }^{\circ} \mathrm{C}$ in February. The minimum value was $13.57{ }^{\circ} \mathrm{C}$ in January, while it was $14.1{ }^{\circ} \mathrm{C}$ in February. The trend of the curve of calculated values as well as experimental value of plant temperature is similar. It increases from morning with increase in time and reaches maximum value at about 12 am and then decreases. It can be observed that, the maximum difference between measured and predicted temperature was $4.1{ }^{\circ} \mathrm{C}$ in January figure (8). The minimum correlation coefficient between values was 0.977 in January figure (9).

Further, results show that the calculated values of plant temperature are matching very well with the measured experimental values. 


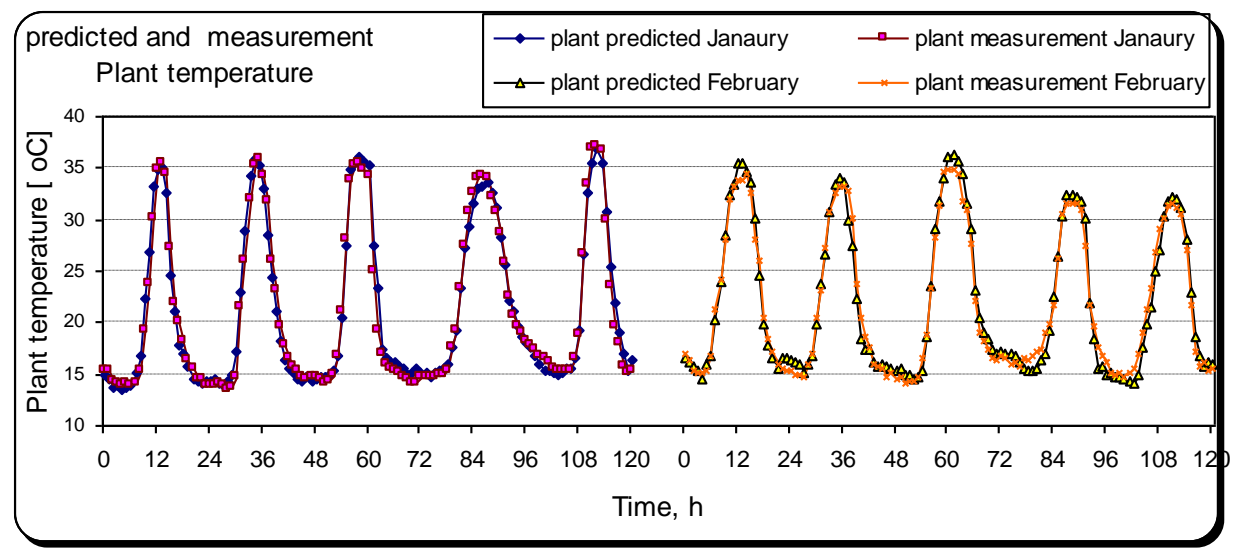

Fig.7: predicted and measured plant temperature.

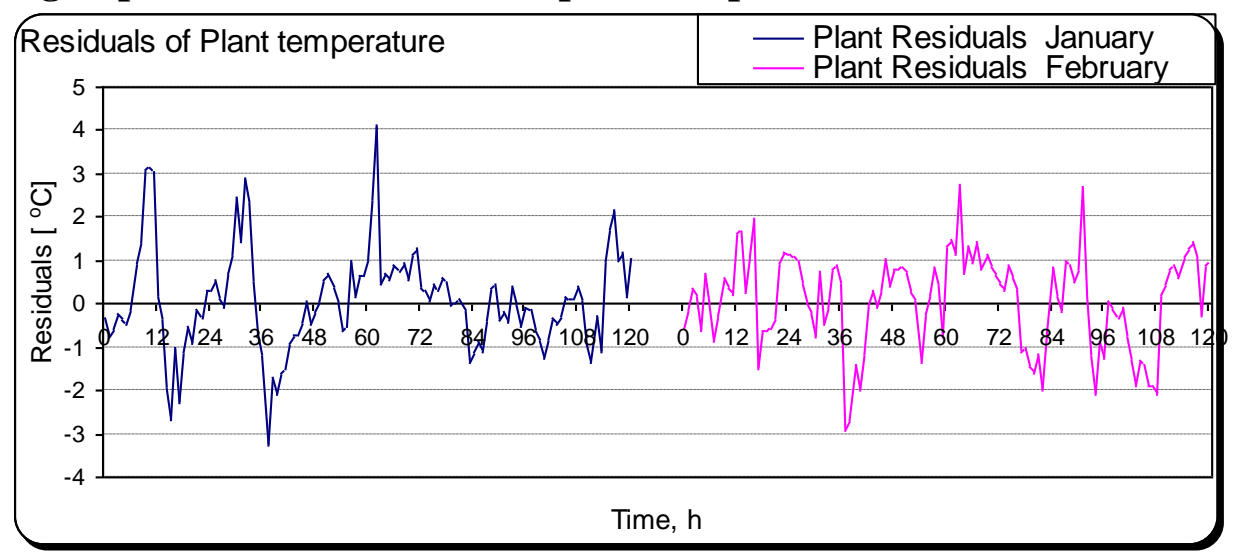

Fig.8: Residuals of the measured and predicted plant temperature.
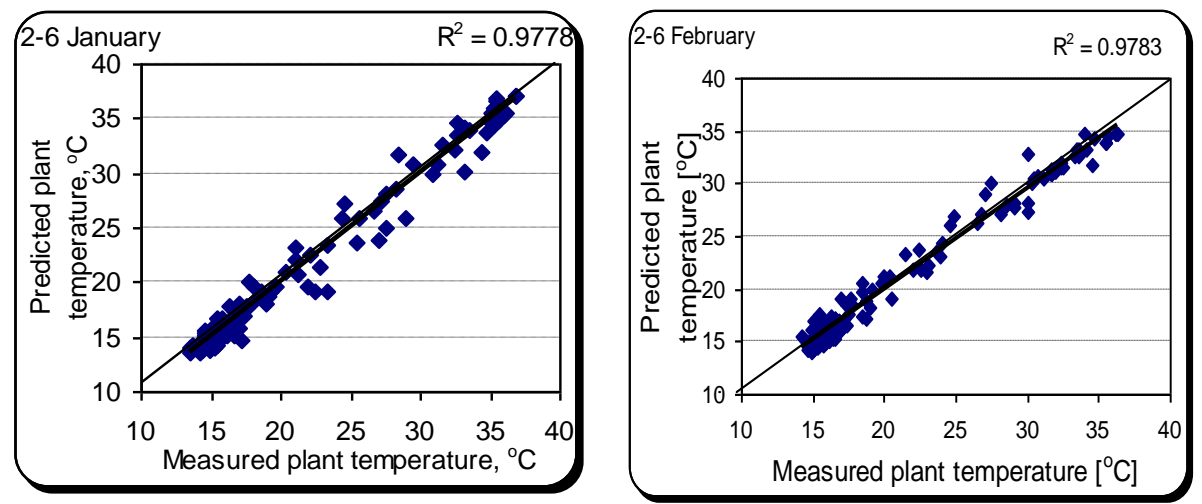

Fig. 9: Comparison between measured and predicted of the plant temperature.

Misr J. Ag. Eng., July 2011 


\subsection{Greenhouse cover temperature}

The cover is the important element in the greenhouse construction for Keeping of the energy. Temperature of the cover is an essential parameter needed for any analysis of energy transfer in the greenhouses technology. The energy transfer to inside greenhouse from the cover in the day time and in the night the energy transfer from the greenhouse to the outside air because of the variation in the inside air temperature. For this, it is observed; that the cover temperature during sunshine hours is higher than the room temperature, whereas the trend is reversed during night hours. The predicted temperatures of cover of greenhouse using the computer model along with measured values at different time of the day are shown in figure (10). Similarly, simulations data were compared with measurements at tow periods of 5 consecutive days.

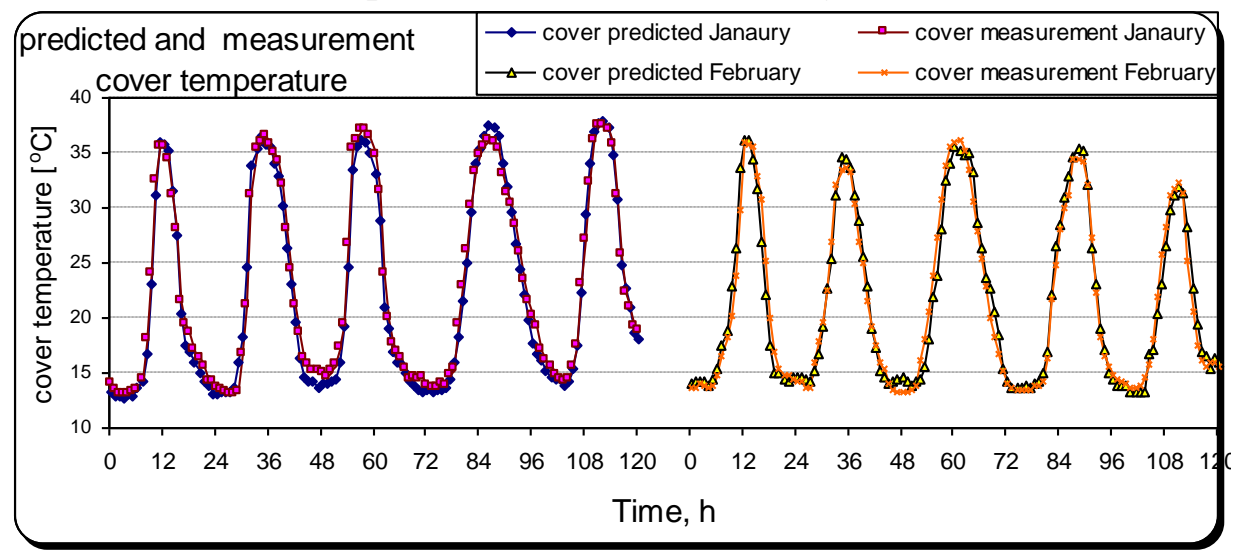

Fig. 10: predicted and measured cover greenhouse temperature.

Figure (10) presents the simulation results obtained from the model during the simulation periods and the measurement in the same time. The cover temperature reached to the maximal value was $37.87{ }^{\circ} \mathrm{C}$ in January, while it was $36.13{ }^{\circ} \mathrm{C}$ in February. And the minimum values were 12.77 ${ }^{\circ} \mathrm{C}$ in January, while it was $13.24{ }^{\circ} \mathrm{C}$ in February. It can be observed that, the maximum difference between measured and predicted temperature was $3.8^{\circ} \mathrm{C}$ in February figure (11). 


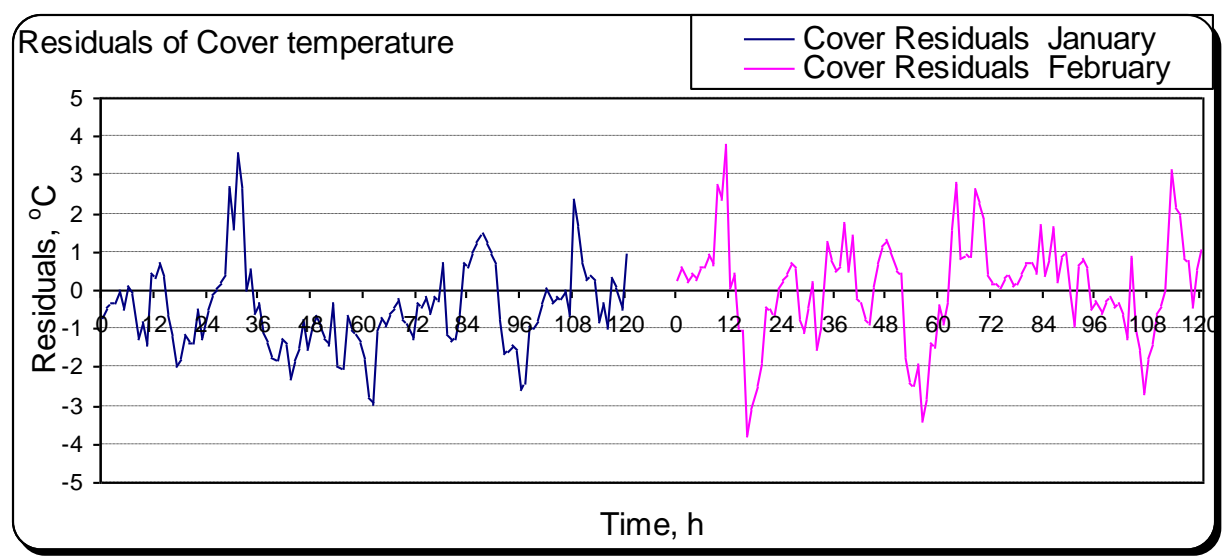

Fig.11: Residuals of the measured and predicted cover temperature.
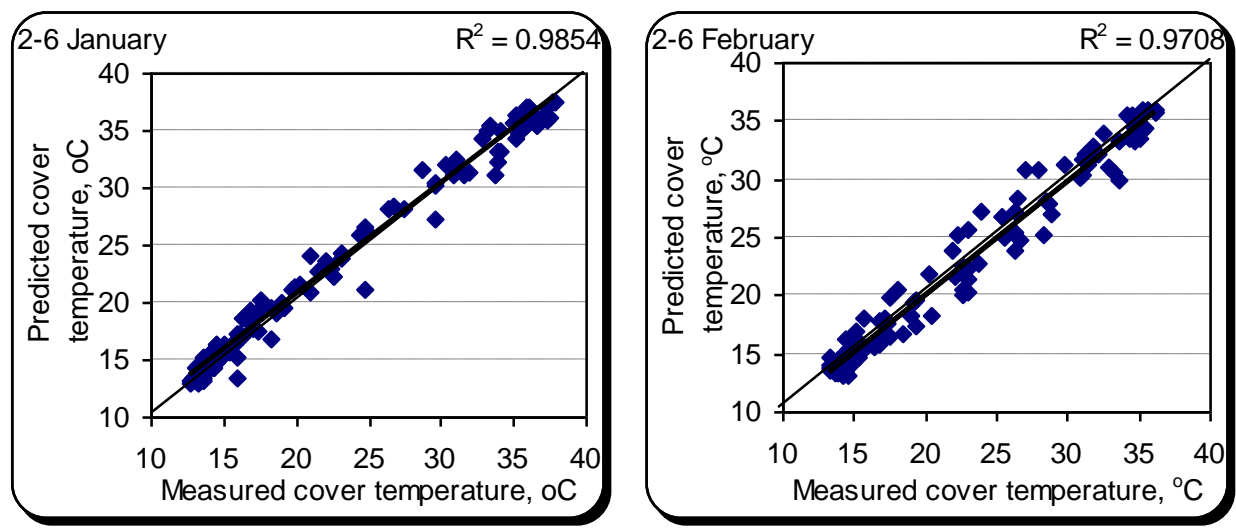

Fig.12: Comparison between measured and predicted of the cover temperature.

The minimum correlation coefficient between values was 0.970 in February figure (12). There is a correspondence between the simulated and the measured cover temperatures.

\subsection{Greenhouse soil temperature}

A popular and economical heat storage material is the soil. Sensible heat storage (with air as the energy transport mechanism) placed underground have the advantage of providing a large and cheap heat transfer surface. Where the heat is absorbed through the cover during the period of the brightness of the sun all day long, then a reverse process occurs during the evening ( the soil surface works as a heat exchanger), which retrieves 
the most of the heat absorbed during the day and thus help in heating the greenhouse.

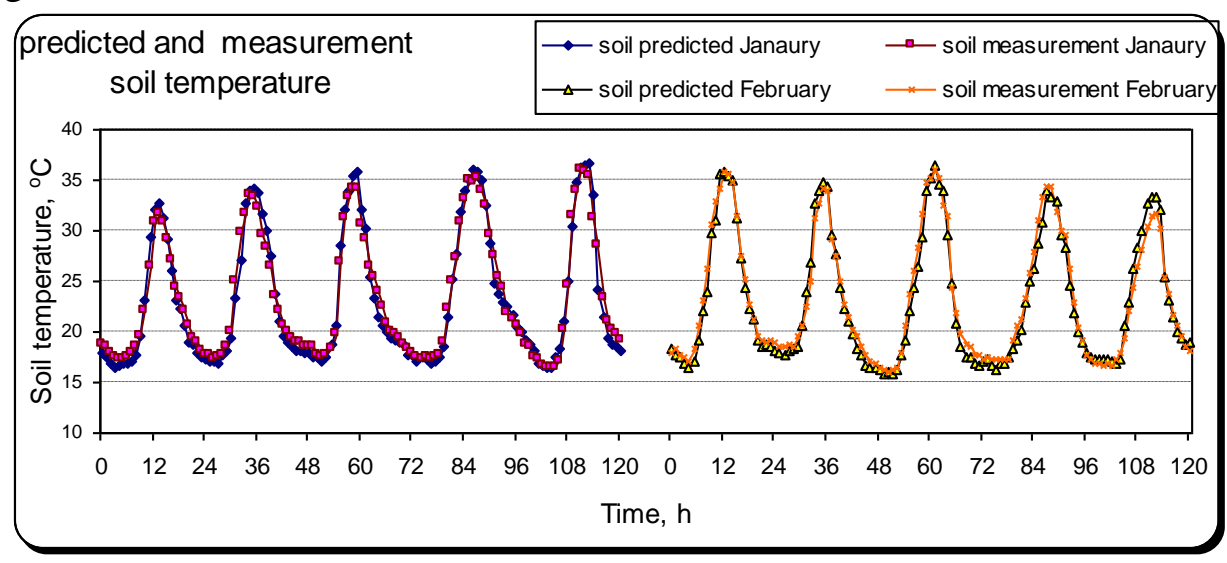

Fig.13: predicted and measured soil temperature.

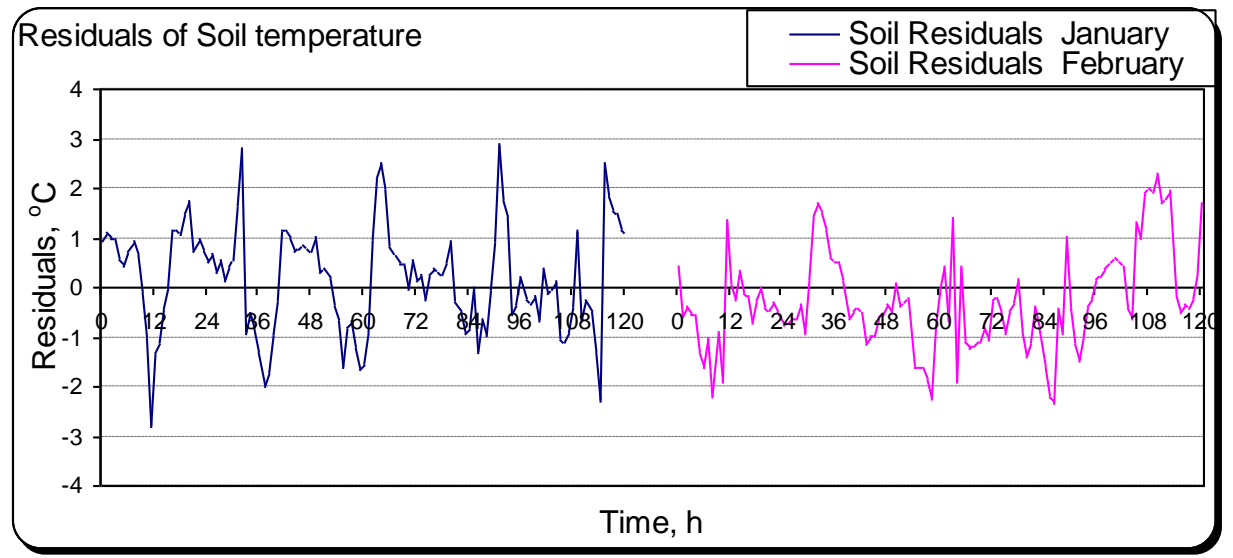

Fig.14: Residuals of the measured and predicted soil temperature.

Figure (13) show the time evolution of the simulated and measured soil surface temperatures for 10 successive days. It was observed that the soil surface temperature fluctuated and increased over time from January until February and the soil temperature reached the maximal value was 36.64 ${ }^{\circ} \mathrm{C}$ in January, while it was $36.4{ }^{\circ} \mathrm{C}$ for February. And the minimum values were $16.3{ }^{\circ} \mathrm{C}$ in January, while it was $15.8{ }^{\circ} \mathrm{C}$ in February. It can be observed that, the maximum difference between measured and predicted temperature was $4.32{ }^{\circ} \mathrm{C}$ in January figure (14). The minimum correlation coefficient between values was 0.975 in January figure (15). 
And there is a correspondence between the simulated and the measured soil temperatures inside the greenhouse. The soil temperature inside greenhouse is influenced by air temperature outside the greenhouse, incident global solar radiation, heat capacity of the soil, conductivity of the soil and heating system.
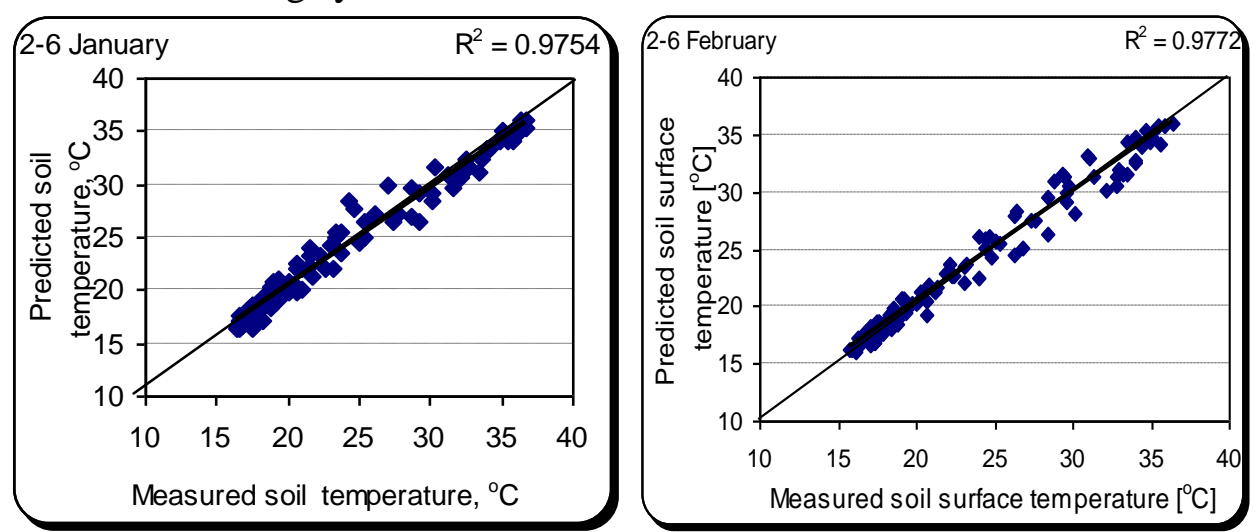

Fig.15: Comparison measured and predicted of the soil temperature

\subsection{The Relative Humidity.}

The trend of the curve of calculated values in line with experimental values of relative humidity of inside air is similar but not good degree. It decreases from morning with increase in time and reaches minimum at about $2 \mathrm{pm}$ and then increases. The relative humidity inside the greenhouse reached the maximal value were $96.2 \%$ in January, while it was $87.36 \%$ for February. And the minimum values were $66.11 \%$ in January, while it was $63.88 \%$ for February.

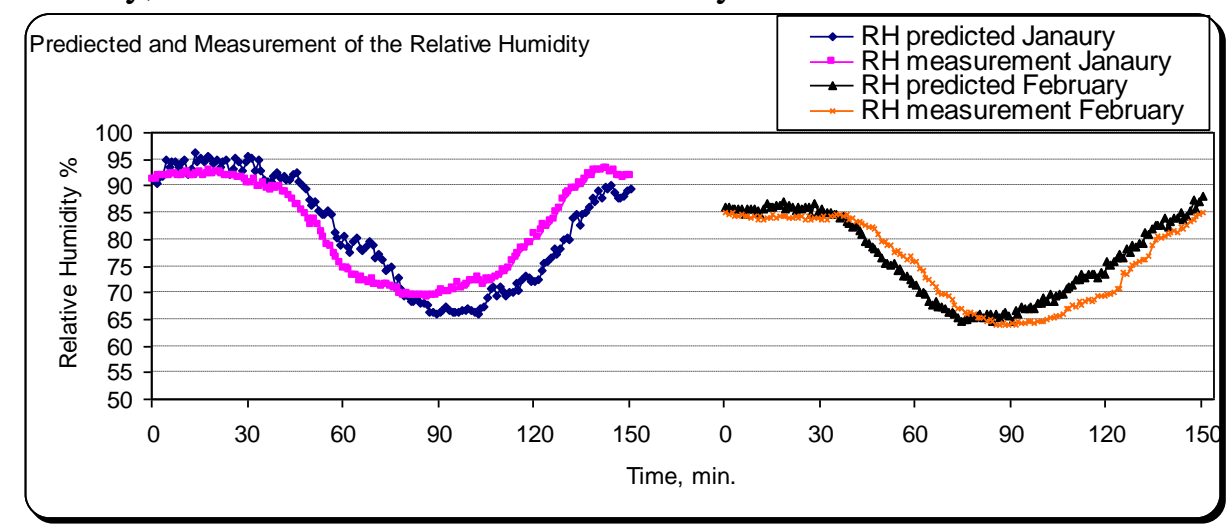

Fig.16: predicted and measured relative humidity. 
Figure (16) represents the differences between the measured and the predicted values of the inside relative humidity $\%$ during the simulation periods. The maximum differences between measured and predicted values profile are $9 \%$ in January, while it was $6.31 \%$ for February. The minimum correlation coefficient between values was 0.818 in January figure (17).
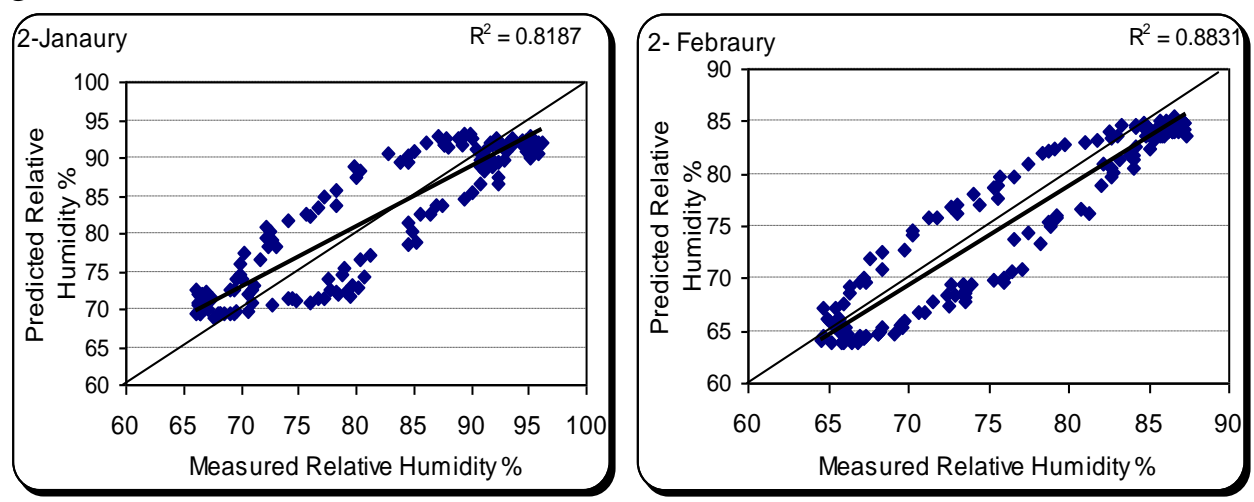

Fig.17: Comparison between measured and predicted of the relative humidity. CONCLUSION

1-Using waste heat as an input for greenhouse operations is a new mechanism for reducing operating costs.

2- As a whole, a good agreement between the predicted and measured values was obtained during the entire modelling period. This means that the model can be used to predict a thermal performance of the greenhouse elements in a wide range of solar radiation and temperatures.

\section{REFERENCES}

Abd el Menem, A. (1998). Protected cultivation technology (GREENHOUSE)

Amon, T.; Amon, B. and Kryvoruchko, V. (2007). Methane production through anaerobic digestion of various energy crops grown in sustainable crop rotations Bioresource Technology $98: 3204-3212$

Boulard, T.; Razafinjohany, E.; Baille, A.; Jaffrin, A. and Fabre, B. (1990). Performance of a greenhouse heating system with a phase change material. Agricultural and Forest Meteorology 52, 303-318. 
EL Sheikh, I.H. (2001).soil heating and climate simulation model for greenhouses. Ph.D. Thesis, University of Hannover, Germany.

Gautam, R.; Baral, S. and Heart, S. (2007). Biogas as a sustainable energy source in Nepal: Present status and future challenges Renewable and Sustainable Energy Reviews(2007), doi:10.1016/j.rser.2007.07.006

Harmanto; Tantau1, H.J. and Salokhe, V.M.(2006). Microclimate and Air Exchange Rates in Greenhouses covered with Different Nets in the Humid Tropics Biosystems Engineering (2006) 94 (2), 239-253 doi:10.1016/j.biosystemseng.2006.02.016

He, J. ; Hoyano, a. and Asawa, T. (2009). A numerical simulation tool for predicting the impact of outdoor thermal environment on building energy performance. Applied Energy, 85: 1595-1505

Kumari, N.; Tiwari, G.N. and Sodha, M.S. (2003). Modelling of a greenhouse with integrated solar collector for thermal heating. International Journal of Ambient Energy 27 (30), 125-136.

Lewis, M. J. (1990). Physical properties of foods and food processing systems. Ellis Horwood Limited.

Mutwiwa, U. N. (2007). Effects of Different Cooling Methods On Microclimate and Plant Growth in Greenhouses In The Tropics. Ph.D. Thesis, University of Hannover, Germany.

Oeztuerk, H.H. and Ba-s-cetin-celik, A. (2003). Energy and Exergy Efficiency of a Packed-bed Heat Storage Unit for Greenhouse Heating Biosystems Engineering (2003) 86 (2), 231-245

Oeztuerk, H.H. (2005). Experimental evaluation of energy and exergy efficiency of a seasonal latent heat storage system for greenhouse

Seginer, I. and Albright Louis, D. (1980). Rational operation of greenhouse thermal-curtains. Transactions of the ASAE 1980:124045.

Shukla, A.; Tiwari, G.N. and Sodha, M.S. (2006). Thermal modeling for greenhouse heating by using thermal curtain and an earth-air heat 
exchanger Building and Environment 41 (2006) 843-850

Singha, G.; Parm Pal Singhb, P.; Lubanaa, P.P. S. and Singh K.G (2006). Formulation and validation of a mathematical model of the microclimate of a greenhouse Renewable Energy $31: 1541-1560$

Strauch, K.-H. (1985). Geschlossene Gewächshaussysteme mit integrierter solarer Wasserentsalzungsanlage für aride Gebiete. Gartenbautechnische Informationen 22, Universität Hannover.

Taha, A. T.; Eissa, A. H.; Gamea, G.R. and Hidarh, H. M. (2009). Simulation model of flat plat solar collector performance. In the $1 \mathrm{St}$ Scientific conference for marketing the applied university research, Minoufiya University, Egypt, (pp. 421-438), 7-8 October, 2009.

Taha, A.T. (2003). Simulation Model of Energy Fluxes in Passive Solar Greenhouses with a Concrete North-Wall. Ph.D. Thesis, University of Hannover, Germany.

Tantau, H.-J. (1983). Heizunganlagen im Gartenbau. Ulmer, Stuttgart.

Tantau, H.-J. (1998). Greenhouse climate - overview. Modelling, Control and Optimization greenhouse, drying and Farm Energy System.

Tiwaria, G. N.; Akhtarb, M. A.; Shuklaa, A. and Emran Khan, M. (2006). Annual thermal performance of greenhouse with an earthair heat exchanger: An experimental validation Renewable Energy 31 (2006) 2432-2446

Von Elsner, B. (1982). Das Kleinklima der Wärmeverbrauch von Geschlossenen Gewächshäusern „Ein Simulationsmodell zur Gartenbautechnischen Bewertung unterReferences132 Berücksichtigung des Einflusses von Standortklima, Pflanzenbestand undGewächshauskonstruktion. Gartenbautechnische Informationen 12, Universität Hannover. Cited from EL Sheikh, I.H. (2001).soil heating and climate simulation model for greenhouses. Ph.D. Thesis, University of Hannover, Germany .

Willits, D.H.; Marbis, J. M. and Cheng, J. (2003). Waste Heat Utilization in a Greenhouse Used for the Removal of Nutrients from a Swine Waste Stream 


\section{الملخص العربي}

موديل رياضمى لتدفئة الصوب الزراعيه باستخدام حرارة غاز مات العادم التاتجه من محرك يعمل بوقود البيوجاز

د/ جمال رشاد جامع" د/ محمد عبد الفتاح عبد المقصود* م.م/ محمد نبيه بيومى عمر **

الصوبات الزر اعيه هي واحدة من اهم التقنيات الزراعية في إنتاج المحاصيل في ظل ارتفاع عدد

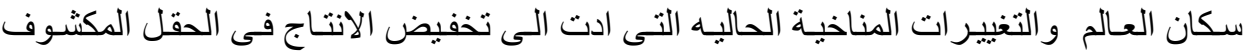
والارتفاع الكبير فى اسعار الخضار . وهناك العديد من طرق المستخدمه في تدفئه الصوب.

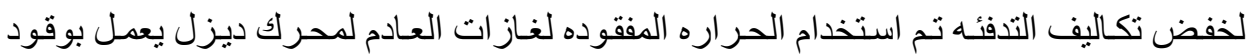
البيوجاز وذللك للاستفاده من هذه الطاقه المهدره فى تدفئة الصوبه الزر اعبـه.ولتحقيق هذا الهدف

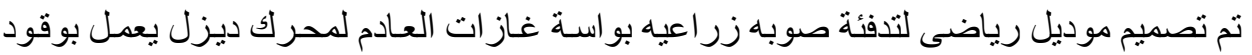

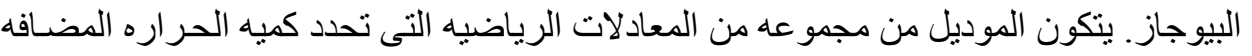

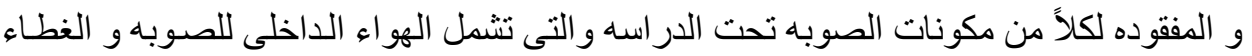

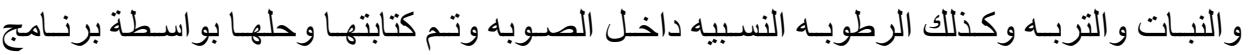

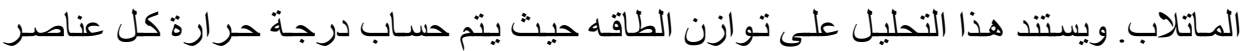

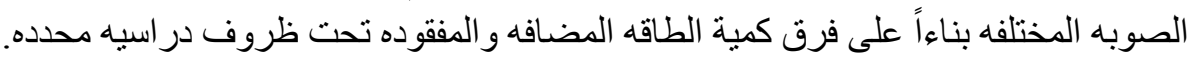

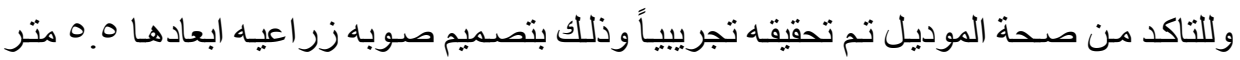

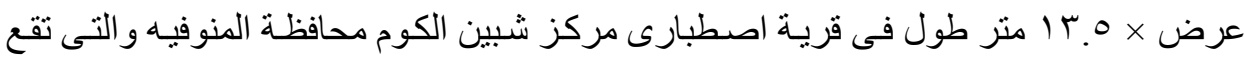

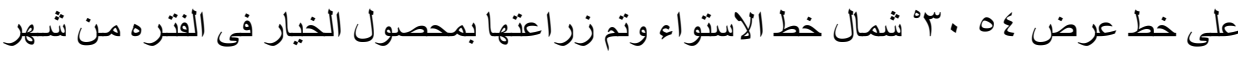

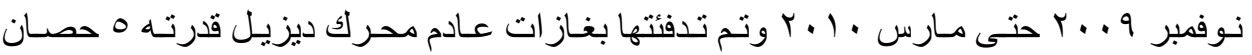

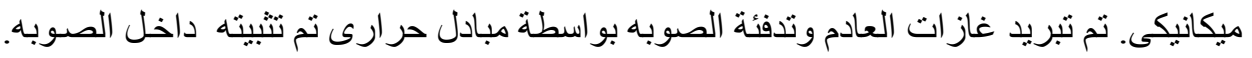

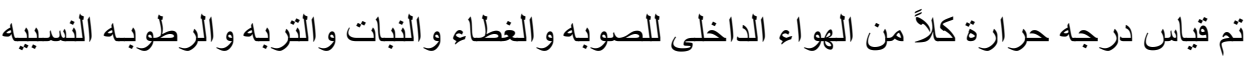

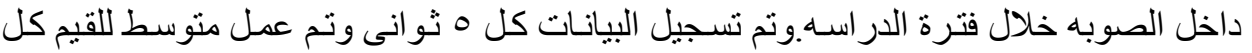

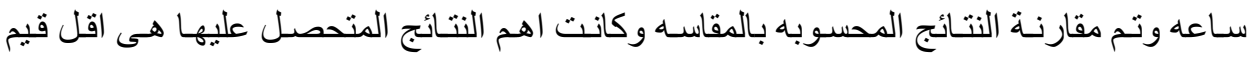

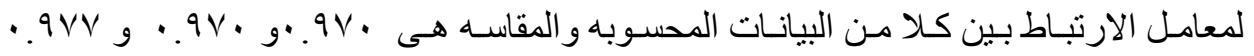

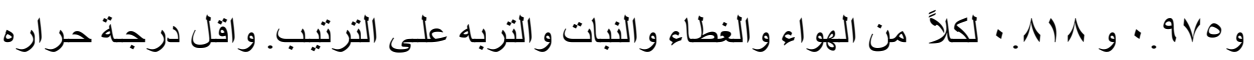

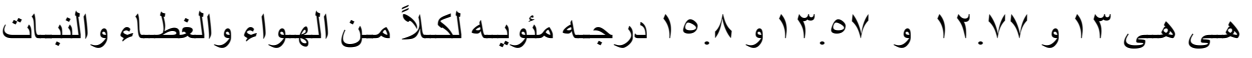
و التربه على الترتيب.ومن خلال النتائج تم الحصول على اتفاق جيد بين القيم المقاسـه والمحسوبه

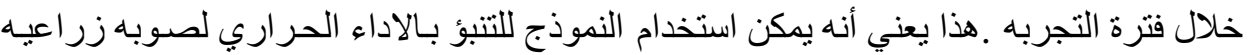

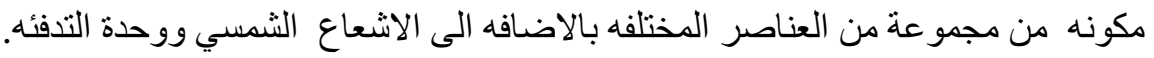

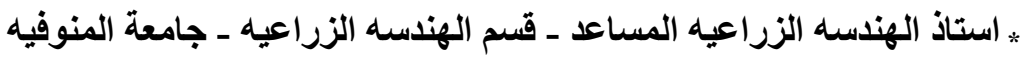

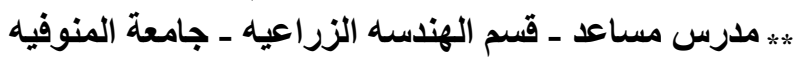

